Vol 11, Issue 4, 2018

\title{
ASSESSMENT OF MEDICATION ADHERENCE AMONG PATIENTS WITH HYPERTENSION AND DIABETES MELLITUS IN URBAN FIELD PRACTICE
}

\author{
MANIKANDAN R ${ }^{1 *}$, NANDAMURI SRI SAI SUDHA ${ }^{1}$, LOGARAJ M ${ }^{2}$ \\ ${ }^{1}$ Department of Pharmacy Practice, SRM College of Pharmacy, SRM Institute of Science and Technology, Kancheepuram, Tamil Nadu, \\ India. ${ }^{2}$ Department of Community Medicine, SRM Medical College Hospital and Research Centre, SRM Institute of Science and Technology, \\ Kancheepuram, Tamil Nadu, India. Email: Manir11101994@gmail.com \\ Received: 23 October 2017, Revised and Accepted: 22 December 2017
}

ABSTRACT

Objective: The present study was conducted to assess the medication adherence among patients with hypertension (HTN) and diabetes mellitus in the urban area of Tamil Nadu and to assess the reasons for non-adherence.

Methods: A cross-sectional study was conducted in an urban area of Tamil Nadu. A total of 100 subjects were enrolled in the study. The patients are diagnosed with HTN and diabetes was included in the study. Morisky medication adherence scale was used to measure adherence among the selected subjects and each patient's details were regarding non-adherence was noted. The results were tabulated.

Results: In our study, the medication adherence of the patients was $84 \%$ and the non-adherence patients were $16 \%$. Medication adherence was found to be more in male (58\%) when compared with females (42\%). In our study, the reasons for non-adherence include high drug cost was more when comparing other factors. In our study, the patients receiving drugs from the medical shop were more comparing with government and private hospitals.

Conclusion: A four-fifth of the subjects is adherence to the prescribed medications. The patients having poor medication adherence due to the high cost of the drug and forgot to take use their medication.

Keywords: Medication adherence, Hypertension, Diabetes mellitus, Morisky scale.

(c) 2018 The Authors. Published by Innovare Academic Sciences Pvt Ltd. This is an open access article under the CC BY license (http://creativecommons. org/licenses/by/4. 0/) DOI: http://dx.doi.org/10.22159/ajpcr.2018.v11i4.23236

\section{INTRODUCTION}

Arterial blood pressure is "normal" when the systolic pressure is $90-119 \mathrm{mmHg}$ and the diastolic pressure is $60-79 \mathrm{mmHg}$. When the arterial pressure is $\geq 120 / 80 \mathrm{mmHg}$, a person is considering being hypertensive [1-3].

Hypertension (HTN) is a chronic disease also commonly treated with drugs that decrease cardiac output. Cardio inhibitors either block beta-adrenoceptors on the heart (i.e., beta-blockers) or L-type calcium channels (i.e., calcium channel blockers), which decreasing heart rate and contractility (inotropy). Vasodilator drugs, which decrease systemic vascular resistance, are used to decrease blood pressure and other drugs such as alpha-adrenoceptor antagonists (alpha-blockers), direct-acting vasodilators, angiotensin-converting enzyme inhibitors, and angiotensin receptor blockers are also used to treat HTN.

Diabetes is a metabolic disorder that is characterized by high blood glucose and either insufficient or ineffective insulin. Type I diabetes, the deficiency of insulin, is due to a decline in the number of beta cells, the pancreas contains. Type II diabetes is the most common form of diabetes, with about $90 \%$ of diabetes falling into the Type II category.

The diabetes can be managed through pharmacological and nonpharmacological approaches includes sulfonylureas, dipeptidyl peptidase-4 inhibitor, insulin, biguanides, metaglinides, thiazolidinedione, alpha-glucosidase inhibitors, sodium glucose transporters, glucagon-like peptides, and lifestyle interventions can reduce the disease burden [4-6].

Medication adherence usually refers to whether patients take their medications as prescribed (e.g., twice daily), as well as whether they continue to take a prescribed medication $[7,8]$.
Various factors affect medication adherence such as the complexity of the prescribed drug regimen, duration of therapy, and many psychosocial factors [9]. Hence, this study is focused on assessing the level of medication adherence in urban area by patients and the factors which hinder them from prescription non-adherence.

The present study was conducted to assess the medication adherence among patients with HTN and diabetes mellitus (DM) in the urban area of Tamil Nadu and to assess the reasons for non-adherence.

\section{METHODS}

The cross-sectional study was conducted in the urban field practice area of SRM Medical College Hospital and Research Center. In our study, a short, validated patient questionnaire "THE MORISKY - INSTRUMENT" is used to measure adherence among the selected subjects. According to this, the individuals who said "NO" to all the four questions are considered to be adherent to the medications. Community-based data collection was done in the urban field practice area of the SRM Medical College, Hospital and Research Centre (NH1-M.M Nagar). The study was conducted for 3 months from January 2017 to March 2017. Informed consent was obtained from all patients participating in this study. The statistical analysis was performed using SPSS version 16.0 (Chi-square test). A total of 100 study subjects (43 DM, 26 hypertensive, and 31 with both DM and HTN) were selected based on the inclusion and exclusion criteria.

\section{Inclusion criteria}

Subjects more than 18 years of ages.

Subjects diagnosed with DM and/or HTN and are willing to participate. Subjects with duration of diabetes and/or HTN 1-15 years.

\section{Exclusion criteria}

Subjects with $<18$ years of ages.

Subjects with complications other than DM and HTN. 


\section{RESULTS}

Among 100 patients recruited, the male patients (diabetes, HTN, and patients diagnosed with HTN and diabetes) were 57 (57\%) and female patients were 43 (43\%) (Table 1).

In our study, the total of $25-55$ age patients was $37 \%$ and $55-75$ age patients were $55 \%$ and $75-95$ age patients were $8 \%$ (Table 2).

In our study, daily $<3$ pills consuming subjects were 8, 3-6 pills consuming subjects were 26 , more than 6 pills consuming subjects were 12 as shown in Table 3.

Table 4 summarizes the average medication cost per a month includes below 3000 cost spending patients were 78\%, 3000-6000 cost spending patients were $6 \%, 6000-9000$ cost spending patient was $1 \%$, and patients receiving free cost of medications were $15 \%$ from government.

Table 1: Gender wise distribution of study subjects $(n=100)$

\begin{tabular}{lllll}
\hline Gender & $\begin{array}{l}\text { Number of } \\
\text { patients DM }\end{array}$ & HTN & $\begin{array}{l}\text { Both } \\
\text { DM+HTN }\end{array}$ & Frequency (\%) \\
\hline Male & 29 & 15 & 13 & $57(57)$ \\
Female & 14 & 11 & 18 & $43(43)$ \\
& & & Total & $100(100)$ \\
& & & Mean \pm SD & $50 \pm 9.89$ \\
\hline
\end{tabular}

Values are expressed in frequency and percentage. SD: Standard deviation, DM: Diabetes mellitus, HTN: Hypertension

Table 2: Age wise distribution of study subjects $(n=100)$

\begin{tabular}{lllll}
\hline Age & $\begin{array}{l}\text { Number of } \\
\text { patients DM }\end{array}$ & HTN & $\begin{array}{l}\text { Both } \\
\text { DM+HTN }\end{array}$ & Frequency (\%) \\
\hline $25-55$ & 19 & 6 & 12 & $37(37)$ \\
$55-75$ & 22 & 16 & 17 & $55(55)$ \\
$75-95$ & 2 & 4 & 2 & $8(8)$ \\
& & & Total & $100(100)$ \\
& & & Mean \pm SD & $33.33 \pm 23.71$ \\
\hline
\end{tabular}

Values are expressed in frequency and percentage. SD: Standard deviation, DM: Diabetes mellitus, HTN: Hypertension

Table 3: Distribution of data based on number of pills per day $(n=100)$

\begin{tabular}{lllll}
\hline $\begin{array}{l}\text { Number of } \\
\text { pills per day }\end{array}$ & DM & HTN & Both DM+HTN & Frequency (\%) \\
\hline$<3$ & 32 & 22 & 8 & $62(62)$ \\
$3-6$ & 9 & 3 & 14 & $26(26)$ \\
$>6$ & 2 & 1 & 9 & $12(12)$ \\
& & & Total & $100(100)$ \\
& & & Mean \pm SD & $33.33 \pm 25.79$ \\
\hline
\end{tabular}

Values are expressed in frequency and percentage. SD: Standard deviation, DM: Diabetes mellitus, HTN: Hypertension

Table 4: Distribution of data based on average cost of medicines spent per month $(n=100)$

\begin{tabular}{lllll}
\hline $\begin{array}{l}\text { The average cost } \\
\text { of medicines spent } \\
\text { per month }\end{array}$ & DM & HTN & $\begin{array}{l}\text { Both } \\
\text { DM+HTN }\end{array}$ & Frequency (\%) \\
\hline $0-3000$ & 34 & 22 & 22 & $78(78)$ \\
$3000-6000$ & 1 & 1 & 4 & $6(6)$ \\
$6000-9000$ & - & - & 1 & $1(1)$ \\
Free cost & 8 & 3 & 4 & $15(15)$ \\
& & & Total & $100(100)$ \\
& & & Mean \pm SD & $25 \pm 35.80$ \\
\hline
\end{tabular}

Values are expressed in frequency and percentage. SD: Standard deviation, DM: Diabetes mellitus, HTN: Hypertension
Table 5 summarizes the patients receiving ayurvedic treatment were $3 \%$ and homeopathic treatments were $2 \%$ and allopathic patients were $95 \%$.

The adherence and non-adherence was assessed using Morisky medication adherence scale. The medication adherence of the patients was $84 \%$ and non-adherence patients were $16 \%$ (Table 6).

The adherence to the prescribed medications was studied. Male (58\%) is having more adherence than female (42\%) (Table 7).

In our study, the reasons for non-adherence include high drug cost $50 \%$, forgetfulness to take the medication include $38 \%$, drug side effects $6 \%$, and drug discontinuation 6\% (Table 8).

Table 9 summarizes the patients are receiving sources of medications include medical shop 48 (48\%), patients receiving drugs from government hospital includes 18 (18\%), and patients receiving drugs from private hospital includes 34 (34\%).

Table 5: Distribution of data based on patients receiving alternative treatment $(n=100)$

\begin{tabular}{lllll}
\hline $\begin{array}{l}\text { Alternative } \\
\text { treatment }\end{array}$ & $\begin{array}{l}\text { Number of } \\
\text { patients DM }\end{array}$ & HTN & $\begin{array}{l}\text { Both } \\
\text { DM+HTN }\end{array}$ & Frequency (\%) \\
\hline Ayurveda & 2 & - & 1 & $3(3)$ \\
Homeopathy & 1 & - & 1 & $2(2)$ \\
Allopathic & 38 & 29 & 28 & $95(95)$ \\
& & & Total & $100(100)$ \\
& & & Mean \pm SD & $33.33 \pm 53.40$ \\
\hline
\end{tabular}

Values are expressed in frequency and percentage. SD: Standard deviation, DM: Diabetes mellitus, HTN: Hypertension

Table 6: Details of the patients regarding adherence and non-adherence based on Morisky medication adherence scale $(n=100)$

\begin{tabular}{llll}
\hline Subjects & Male & Female & Frequency (\%) \\
\hline Adherence & 49 & 35 & $84(84)$ \\
Non-adherence & 8 & 8 & $16(16)$ \\
& & Total & $100(100)$ \\
& & Mean \pm SD & $50 \pm 48.08$ \\
\hline
\end{tabular}

Values are expressed in frequency and percentage. SD: Standard deviation, DM: Diabetes mellitus, HTN: Hypertension

Table 7: Adherence to the prescribed medications $(n=84)$

\begin{tabular}{lllll}
\hline Gender & $\begin{array}{l}\text { Number of } \\
\text { patients DM }\end{array}$ & HTN & $\begin{array}{l}\text { Both } \\
\text { DM+HTN }\end{array}$ & Frequency (\%) \\
\hline Male & 25 & 13 & 11 & $49(58)$ \\
Female & 10 & 10 & 15 & $35(42)$ \\
& & & Total & $84(100)$ \\
& & & Mean \pm SD & $42 \pm 9.89$ \\
\hline
\end{tabular}

Values are expressed in frequency and percentage. SD: Standard deviation, DM: Diabetes mellitus, HTN: Hypertension

Table 8: Reasons for non-adherence $(n=16)$

\begin{tabular}{ll}
\hline Reason & Frequency (\%) \\
\hline Drug cost & $8(50)$ \\
Forgetfulness due to busy schedule & $6(38)$ \\
Side effect & $1(6)$ \\
Discontinuation & $1(6)$ \\
Total & $16(100)$ \\
Mean \pm SD & $4 \pm 3.55$ \\
\hline
\end{tabular}

Values are expressed in frequency and percentage. SD: Standard deviation, DM: Diabetes mellitus, HTN: Hypertension 
Table 9: Sources of collecting medication $(n=100)$

\begin{tabular}{lllll}
\hline $\begin{array}{l}\text { Sources of } \\
\text { collecting } \\
\text { medication }\end{array}$ & DM & HTN & $\begin{array}{l}\text { Both } \\
\text { patients } \\
\text { with } \\
\text { DM+HTN }\end{array}$ & Frequency (\%) \\
\hline $\begin{array}{l}\text { Medical shop } \\
\begin{array}{l}\text { Government } \\
\text { hospital }\end{array}\end{array}$ & 9 & 18 & 16 & $48(48)$ \\
$\begin{array}{l}\text { Private hospital } \\
\text { 16 }\end{array}$ & 16 & 8 & 5 & $18(18)$ \\
& & & $\begin{array}{l}10 \\
\text { Total } \\
\text { Mean } \pm S D\end{array}$ & $\begin{array}{l}34(34) \\
100(100)\end{array}$ \\
\hline
\end{tabular}

Values are expressed in frequency and percentage. SD: Standard deviation, DM: Diabetes mellitus, HTN: Hypertension

\section{DISCUSSION}

The numbers of subjects are recruited in the study as similar to the previous studies [10-12].

In our study, 55-75 patients age patients were more when compared with other age groups. In our study, $<3$ pills using patients were more (62\%) compared with other pills consuming subjects. The healthcare costs spending per month patients were included $0-3000$ cost patients were more when compared with the other costs which are similar to previous studies.

In our study, the reasons for non-adherence were found to be high drug costs $(50 \%)$, forgetfulness to take the medication (38\%), and drug side effects $(6 \%)$ which are similar to previous studies conducted by Medi et al., in 2015, among south Indian diabetes patients [13].

Allopathic treatment, patients were more when compared with Ayurveda and homeopathy treatments. In our study, it was observed that male diabetic patients have more medication adherence compared to others which is in concordance with the previous studies. In our study, medication adherence patients were (84\%) more when comparing nonadherence patients (16\%) which are quite similar to the study conducted by Ramli et al. where the medication adherence is 53.4\% [16].

HTN and diabetes are major chronic diseases in the world. Early detection and screening programs can arrest the progressing of disease complications [14]. The lifestyle interventions and regular blood glucose levels monitoring and regular medication practice and were needed for the patients to prevent further disease complications. The informational booklet and patient counselling were effective in increasing patient compliance [15-17].

In our study, the patients receiving drugs from the medical shop were more compared to government and private hospitals. A small number of subjects were recruited in the study is the main limitations of the study.

\section{CONCLUSION}

A four-fifth of the subjects is adherence to the prescribed medications. The patients have poor medication adherence due to the high cost of the drug and forgetfulness to take their medication. Hence, the pharmacist's role is important for the improvement of patient medication adherence by providing patient counseling services and by creating awareness regarding disease.

\section{AUTHOR'S CONTRIBUTIONS}

Manikandan R: Interpretation of data, drafting of report and approval of the version to be published. Nandamuri Sri Sai Sudha: Interpretation of data, drafting of report and approval of the version to be published. Logaraj M: Interpretation of data, revising of report for important intellectual content and approval of the version to be published.

\section{CONFLICTS OF INTEREST}

None.

\section{REFERENCES}

1. Mant J, McManus RJ. Does it matter whether patients take their antihypertensive medication as prescribed? The complex relationship between adherence and blood pressure control. J Hum Hypertens 2006;20:551-3.

2. Rwegerera GM. Adherence to antidiabetic among patients with Type II diabetes at Muhimbii national hospital, Dar Es Selaam, Tanzania-A cross sectional study. Pan Afr Med J 2014;17:252.

3. Rampal L, Rampal S, Azhar MZ, Rahman AR. Prevalence, awareness, treatment and control of hypertension in Malaysia: A national study of 16,440 subjects. Public Health 2008;122:11-8.

4. Fung V, Huang J, Brand R, Newhouse JP, Hsu J. Hypertension treatment in a medicare population: Adherence and systolic blood pressure control. Clin Ther 2007;29:972-84.

5. Khalil SA, Elzubier AG. Drug compliance among hypertensive patients in Tabuk, Saudi Arabia. J Hypertens 1997;15:561-5.

6. Bovet P, Burnier M, Madeleine G, Waeber B, Paccaud F. Monitoring one-year compliance to ant hypertension medication in the Seychelles. Bull World Health Organ 2002;80:33-9.

7. Elbur AI. Levels of Adherence to the lifestyle changes and medication among male hypertensive patients in two hospitals in taif; Kingdom of Saudi Arabia. Int J Pharm Sci 2015;7:168-72.

8. Ho PM, Bryson CL, Rumsfled JS. Medication adherence: Its importance in cardiovascular outcomes. Circulation 2009;119:3028-35.

9. Lavakumar S, Jesurun RS. A study on the level of drug compliance among the outpatients who are on a long-term drug therapy in a tertiary care teaching hospital at Kancheepuram district in Tamil Nadu. Asian J Pharm Clin Res 2017;10:174-6.

10. Alkharfy KM, Ahmed NJ, Aljirs WS, Rabba AK. Medication adherence in Type 2 diabetics'patients: A study in Saudi Arabia. Int J Pharm Sci 2017;9:247-50.

11. Briadar SS, Rajashekhar K, Srinivas R, Raju SA. Assessment of pharmacist mediated patient counseling on medication adherence in hypertension patients of south Indian city. Int Res J Pharm 2012;3:251-5.

12. Alekhya P, Sriharsha M, Ramudu RV, Shivanandh B, Darsini TP, Reddy KS, et al. Adherenceto antidepressant therapy: Sociodemographic factor Wise distribution. Int J Curr Pharm Res 2015;7:180-4.

13. Medi RK, Mateti UV, Kanduri KR, Konda SS. Medication adherence and determinants of non-adherence among south Indian diabetes patients. J Soc Health Diabetes 2015;3:26-9.

14. American Diabetes Association. Standards of medical care in diabetes. Diabetes Care 2005;28:S4-S36.

15. Sharma T, Kalra J, Dhasmana DC, Basera H. Poor adherence to treatment: A major challenge in diabetes. JIACM 2014;15:26-9.

16. Ramli A, Ahmad NS, Paraidathathu T. Medication adherence among hypertensive patients of primary health clinics in Malaysia. Patient Prefer Adherence 2012;6:613-22.

17. Presetiawati II, Andrajati R, Sauriasari R. Effectiveness of a medication booklet and counseling on treatment adherence in Type 2 diabetes mellitus patients. Int J Appl Pharm 2017;9:27-31. 